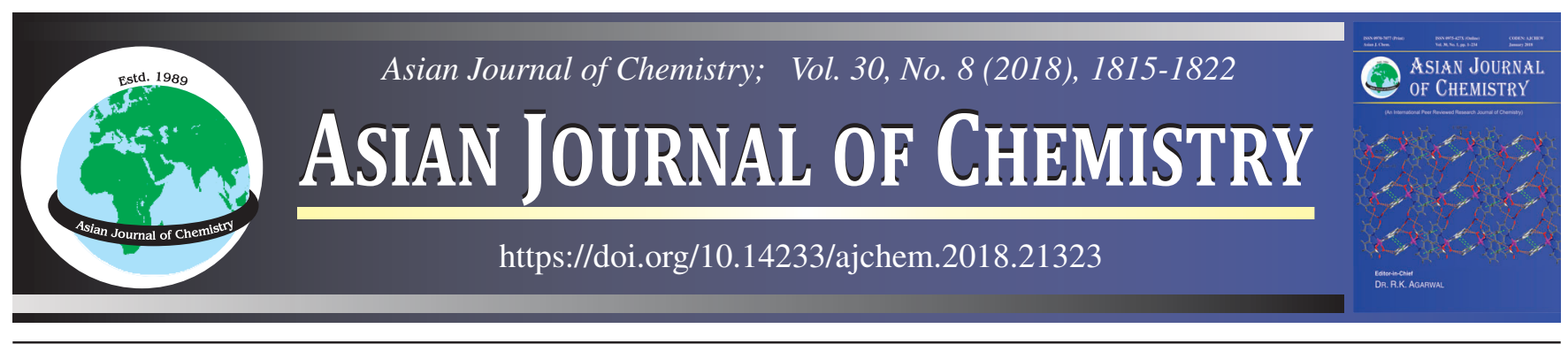

\title{
Synergistic Influence of Halide Ions on Corrosion Inhibition Performance of Gum Exudates of Azadirachta indica on Carbon Steel in Sulphuric Acid Medium
}

Malarvizhi Manickam ${ }^{1, *}$, Dheenadhayalan SivakumaR ${ }^{2}$ and Mallika Jaganathan ${ }^{2}$

${ }^{1}$ Department of Chemistry, Sri GVG Visalakshi College for Women, Udumalpet-642 128, India

${ }^{2}$ Department of Chemistry, PSG College of Arts and Science, Coimbatore-641 014, India

*Corresponding author: E-mail: malar_gvg@rediffmail.com

Received: 7 March 2018;

Accepted: 17 May 2018;

Published online: 30 June 2018;

AJC-18980

The effect of halide ions on the inhibitive performance of gum exudates of Azadirachta indica on carbon steel in $1 \mathrm{~N}$ sulphuric acid medium was investigated using chemical and electrochemical methods. Effect of temperature and immersion period on mitigation performance was studied. The inhibition efficiency of gum exudates of Azadirachta indica considerably increased with the presence of halide ions at all temperature ranges studied. Synergistic influence of halide ions on gum exudates of Azadirachta indica for carbon steel corrosion was reported. Adsorption of gum exudates of Azadirachta indica as well as the inhibitor mixtures are spontaneous and the process followed Langmuir adsorption isotherm. SEM studies supported the adsorption phenomenon.

Keywords: Azadirachta indica gum, Corrosion inhibitor, Electrochemical studies, Synergistic effect, Halide ions.

ᄂ - - - - - - - - - - - - - - - - - - - - - - - - - - - - -

\section{INTRODUCTION}

Carbon steel finds extensive use in oil refineries, distillation plants petrochemical industries, power plants, gas refineries and ships due to its high strength, low cost and easy accessibility [1]. Nevertheless, a huge problem towards application part of carbon steel is its corrosion especially in acid media. Steel corrosion in acidic medium can be minimized through several approaches. Use of synthetic organic and inorganic compounds as corrosion inhibitors is the well-established method but is much expensive and non-biodegradable. To prevail with the condition, bountiful number of corrosion research studies were done using extracts of different parts of plants, natural products, drugs and biopolymers.

Some investigations of gum exudates of trees reported as good inhibitors made in the recent past include gum arabic [2], locust bean gum [3], guar gum [4], albizia gum [5], Raphia hookeri exudate gum [6], Dacryodes edulis gum [7], Ficus glumosa gum [8], Commiphora kerstingii gum [9], Ficus benjamina gum [10], Anogeissus leiocarpus gum [11], Commiphora pendunculata gum [12], Ficus platyphylla gum [13], Ficus trichopoda gum [14], Gloriosa superba gum [15], Khaya ivorensis gum [16], Ficus thonningii gum [17] and Daniella oliveri gum [18]. In general, to improve efficiency of naturally occurring substances, a small addition of halide ions are employed [19-21]. We had reported earlier the use of Azadirachta indica gum for mild steel corrosion in hydrochloric acid medium [22]. The current research work is focused on the impact made by halide ions in gum exudates of Azadirachta indica (GAI) performance for corrosion control of carbon steel in sulphuric acid medium. Gravimetric methods and electrochemical methods were made used to obtain the inhibition efficiency of GAI and surface morphological studies were carried out by using SEM studies.

Gum exudate of Azadirachta indica is basically a salt of complex polysaccharide which is obtained from Melia azadirachta [23]. Anderson and Hendrie [24] reported that neem gum contains:

- $35 \%$ of proteinaceous material which is mostly made of mainly serine, threonine and aspartic acid.

- A very complex carbohydrate component which constitutes D-glucose, D-glucoronic acid, arabinose, fucose, mannose, xylose, rhamnose, D-glucosamine, D-galactose and aldobiuronic acid.

From the above facts, it can be ascribed that GAI with its larger size, typical hetero atoms and sensitive functional groups could adsorb onto the metal surface in an extensive manner subsequently reducing the corrosion rate.

\section{EXPERIMENTAL}

Metal specimen: Rectangular shaped carbon steel specimens with a dimension of $25 \mathrm{~mm} \times 10 \mathrm{~mm} \times 1 \mathrm{~mm}$ were used to carry out the gravimetric experiments. The composition of the coupon was (in wt \%) $0.68 \% \mathrm{Mn}, 0.37 \% \mathrm{C}, 0.23 \% \mathrm{Si}, 0.16$ 
$\% \mathrm{Cu}, 0.077 \% \mathrm{Cr}, 0.0059 \% \mathrm{Ni}, 0.016 \% \mathrm{~S}, 0.011 \% \mathrm{Ti}, 0.00$ $9 \%$ Co (in wt. \%), rest being Fe. Prior to experiments, each coupon was polished by 100, 400 and 600 grades of emery sheet, washed with ethanol, cleaned with acetone and dried, stored in desiccator. Double distilled water was used to prepare aggressive medium of analytical grade sulphuric acid. For synergistic studies AnalaR grade potassium salts were used.

Preparation of gum exudate inhibitor: Gum exudates of Azadirachta indica collected locally was dissolved in water and filtered to remove the impurities. The filtrate was then dried to obtain solid GAI, which is found soluble in water.

Methods: The chemical method was carried out as per ASTM [25] standard and electrochemical methods were carried out as previously reported [22]. The surface of the inhibited and uninhibited carbon steel surface was analyzed by SEM studies.

\section{RESULTS AND DISCUSSION}

Weight loss measurements: The corrosion behaviour of carbon steel in the absence and presence of various concentrations of GAI and GAI in combination with halide ions was investigated using weight loss measurements in the temperature range of 303 to $323 \mathrm{~K}$ for 1 and $4 \mathrm{~h}$ immersion period. Corrosion rate, inhibition efficiency and surface area were calculated with the following expressions:

$$
\begin{aligned}
& \text { Corrosion rate }(\mathrm{CR})(\mathrm{mmpy})=87.6 \times \frac{\mathrm{W}}{\rho \mathrm{At}} \\
& \text { Inhibition efficiency }(\mathrm{IE})(\%)=\frac{\mathrm{W}_{\mathrm{o}}-\mathrm{W}_{\mathrm{i}}}{\mathrm{W}_{\mathrm{o}}} \times 100 \\
& \text { Surface coverage }(\theta)=1-\frac{\mathrm{W}_{\mathrm{i}}}{\mathrm{W}_{\mathrm{o}}}
\end{aligned}
$$

where $\mathrm{W}$ is the weight loss, $\rho$ density of carbon steel, $\mathrm{A}$ is the exposed surface area and $t$ is the immersion time. Also $\mathrm{W}_{\mathrm{i}}$ and $\mathrm{W}_{\mathrm{o}}$ are weight loss of carbon steel in the presence and absence of GAI. The corrosion parameters were presented in the Tables 1 and 2. Close inspection of Table-1 shows that with increase in concentration corrosion rate decreases but increases with increase in temperature. It is attributed to dissolution of carbon steel as well as desorption of adsorbed inhibitor increases with increase in temperature. Such a behaviour is ideal for chemical mode of adsorption. Assessment and comparison of Tables 1 and 2 reveal that the rate of corrosion decreased for the solutions containing GAI and GAI + halide ions compared to the blank solution.60 ppm GAI at $303 \mathrm{~K}$ shows an inhibition efficiency of $68.75 \%$ whereas in combination with $1 \mathrm{mM}$ of KI, efficiency is boosted up to $95.31 \%$ for $1 \mathrm{~h}$ immersion time. While in the case of $4 \mathrm{~h}$ immersion time, inhibition efficiency shown by GAI and GAI + KI mixture is found to be 85.20 and 95.40 $\%$ respectively.

To analyze the inhibitor adsorption mechanism in terms of activation energy $E_{a}^{*}$, Arrhenius equation (eqn. 4) related to frequency factor $\mathrm{A}$ is used.

$$
\log C R=\log A-\frac{E_{a}^{*}}{2.303 R T}
$$

Graphs between $\log$ CR and 1/T for different concentrations of GAI in addition with halide ions plotted were presented in Figs. 1a-c and 2a-c for $1 \mathrm{~h}$ and $4 \mathrm{~h}$ immersion periods. This linear regression plots gave straight line with slope $-\mathrm{E}_{\mathrm{a}}{ }^{*} / 2.303$ $\mathrm{R}$ from which activation energy was obtained.
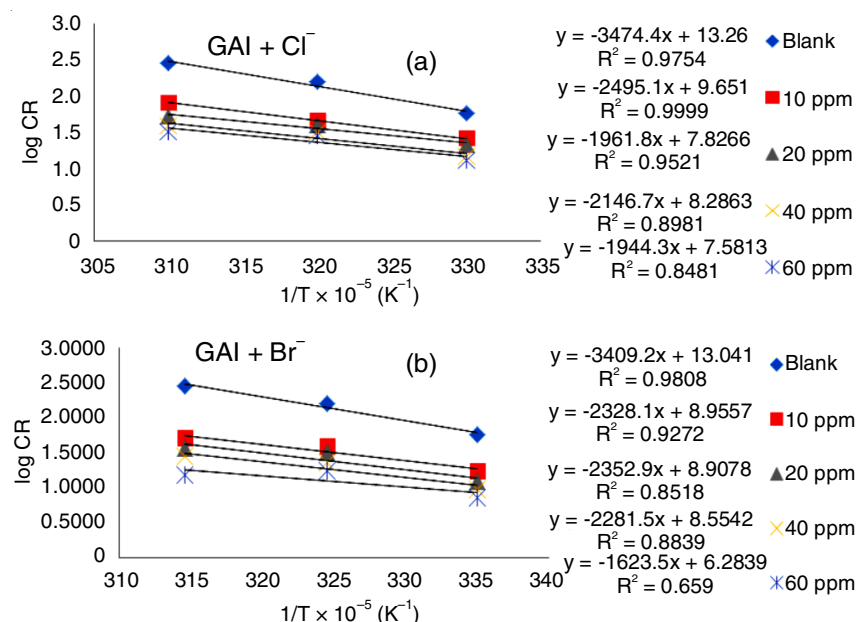

\begin{tabular}{|c|c|c|c|c|c|c|c|c|c|c|}
\hline \multirow[b]{3}{*}{$\begin{array}{l}\text { Immersion } \\
\text { period }(\mathrm{h})\end{array}$} & \multicolumn{9}{|c|}{$\begin{array}{l}\text { TABLE-1 } \\
\text { CORROSION PARAMETERS OBTAINED FROM WEIGHT LOSS MEASUREMENTS FOR CARBON STEEL IN } \\
1 \mathrm{~N} \mathrm{H}_{2} \mathrm{SO}_{4} \text { CONTAINING VARIOUS CONCENTRATIONS OF GAI AT DIFFERENT TEMPERATURES }\end{array}$} & \\
\hline & \multirow[b]{2}{*}{$\begin{array}{l}{[\mathrm{GAI}]} \\
(\mathrm{ppm})\end{array}$} & \multicolumn{3}{|c|}{$303 \mathrm{~K}$} & \multicolumn{3}{|c|}{$313 \mathrm{~K}$} & \multicolumn{3}{|c|}{$323 \mathrm{~K}$} \\
\hline & & $\begin{array}{l}\text { Corrosion } \\
\text { rate } \\
(\mathrm{mmpy})\end{array}$ & $\begin{array}{l}\text { Inhibition } \\
\text { efficiency } \\
\quad(\%)\end{array}$ & $\begin{array}{l}\text { Surface } \\
\text { coverage } \\
\quad(\theta)\end{array}$ & $\begin{array}{l}\text { Corrosion } \\
\text { rate } \\
(\mathrm{mmpy})\end{array}$ & $\begin{array}{l}\text { Inhibition } \\
\text { efficiency } \\
\quad(\%)\end{array}$ & $\begin{array}{c}\text { Surface } \\
\text { coverage } \\
(\theta)\end{array}$ & $\begin{array}{l}\text { Corrosion } \\
\text { rate } \\
(\mathrm{mmpy})\end{array}$ & $\begin{array}{c}\text { Inhibition } \\
\text { efficiency } \\
(\%)\end{array}$ & $\begin{array}{c}\text { Surface } \\
\text { coverage } \\
(\theta)\end{array}$ \\
\hline \multirow{5}{*}{1} & Blank & 57.8620 & - & - & 160.4767 & - & - & 277.5569 & - & - \\
\hline & 10 & 27.5749 & 52.34 & 0.5234 & 78.6562 & 50.99 & 0.5099 & 91.7656 & 66.94 & 0.6694 \\
\hline & 20 & 23.9585 & 58.59 & 0.5859 & 56.5059 & 64.79 & 0.6479 & 63.2866 & 77.20 & 0.7720 \\
\hline & 40 & 19.8901 & 65.63 & 0.6563 & 38.4240 & 76.06 & 0.7606 & 49.2731 & 82.25 & 0.8225 \\
\hline & 60 & 18.0819 & 68.75 & 0.6875 & 33.9035 & 78.87 & 0.7887 & 45.2047 & 83.71 & 0.8371 \\
\hline \multirow{5}{*}{4} & Blank & 56.5165 & - & - & 221.0556 & - & - & 361.8612 & - & - \\
\hline & 10 & 12.8843 & 77.20 & 0.7720 & 124.2078 & 43.81 & 0.4381 & 226.3656 & 37.45 & 0.3745 \\
\hline & 20 & 11.3078 & 80.00 & 0.8000 & 99.5634 & 54.96 & 0.5496 & 209.3024 & 42.16 & 0.4216 \\
\hline & 40 & 9.8334 & 82.60 & 0.8260 & 69.9512 & 68.35 & 0.6835 & 166.8142 & 53.90 & 0.5390 \\
\hline & 60 & 8.3656 & 85.20 & 0.8520 & 64.0210 & 71.04 & 0.7104 & 135.5016 & 62.55 & 0.6255 \\
\hline
\end{tabular}

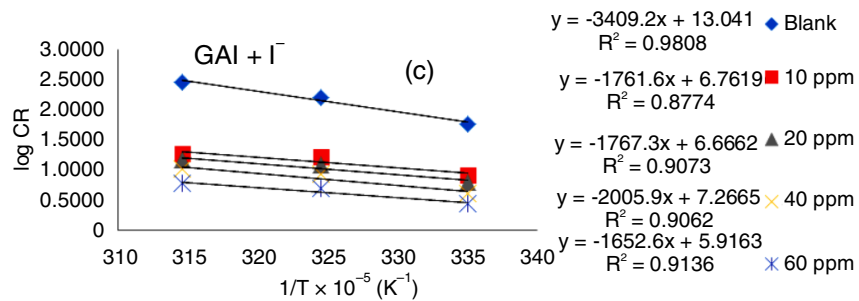

Fig. 1a-c. Arrhenius plots for $\mathrm{GAI}+\mathrm{X}^{-}$ion mixture on carbon steel in $1 \mathrm{~N}$ $\mathrm{H}_{2} \mathrm{SO}_{4}$ for $1 \mathrm{~h}$ immersion period 


\begin{tabular}{|c|c|c|c|c|c|c|c|c|c|c|c|}
\hline \multicolumn{12}{|c|}{$\begin{array}{l}\text { TABLE-2 } \\
\text { CORROSION PARAMETERS OBTAINED FROM WEIGHT LOSS MEASUREMENTS FOR CARBON STEEL IN } 1 \mathrm{~N} \mathrm{H}_{2} \mathrm{SO}_{4} \\
\text { CONTAINING VARIOUS GAI CONCENTRATIONS IN COMBINATION WITH HALIDE IONS AT DIFFERENT TEMPERATURES }\end{array}$} \\
\hline \multirow[b]{2}{*}{$\begin{array}{l}\text { Immersion } \\
\text { period }(\mathrm{h})\end{array}$} & \multicolumn{2}{|c|}{ Concentration } & \multicolumn{3}{|c|}{$303 \mathrm{~K}$} & \multicolumn{3}{|c|}{$313 \mathrm{~K}$} & \multicolumn{3}{|c|}{$323 \mathrm{~K}$} \\
\hline & $\begin{array}{c}\mathrm{X}^{-} \\
(1 \mathrm{mM})\end{array}$ & $\begin{array}{c}\text { GAI } \\
(\mathrm{ppm})\end{array}$ & $\begin{array}{l}\text { Corrosion } \\
\text { rate } \\
(\mathrm{mmpy})\end{array}$ & $\begin{array}{l}\text { Inhibition } \\
\text { efficiency } \\
\quad(\%)\end{array}$ & $\begin{array}{l}\text { Surface } \\
\text { coverage } \\
\quad(\theta)\end{array}$ & $\begin{array}{l}\text { Corrosion } \\
\text { rate } \\
(\text { mmpy })\end{array}$ & $\begin{array}{c}\text { Inhibition } \\
\text { efficiency } \\
(\%)\end{array}$ & $\begin{array}{c}\text { Surface } \\
\text { coverage } \\
(\theta)\end{array}$ & $\begin{array}{l}\text { Corrosion } \\
\text { rate } \\
(\mathrm{mmpy})\end{array}$ & $\begin{array}{c}\text { Inhibition } \\
\text { efficiency } \\
(\%)\end{array}$ & $\begin{array}{c}\text { Surface } \\
\text { coverage } \\
(\theta)\end{array}$ \\
\hline \multirow{12}{*}{1} & \multirow{4}{*}{$\mathrm{Cl}^{-}$} & 10 & 26.22 & 54.69 & 0.5469 & 46.11 & 71.27 & 0.7127 & 82.72 & 70.20 & 0.7020 \\
\hline & & 20 & 21.25 & 63.28 & 0.6328 & 39.78 & 75.21 & 0.7521 & 52.44 & 81.11 & 0.8111 \\
\hline & & 40 & 14.47 & 75.00 & 0.7500 & 31.64 & 80.28 & 0.8028 & 38.88 & 85.99 & 0.8599 \\
\hline & & 60 & 13.11 & 77.34 & 0.7734 & 28.48 & 82.25 & 0.8225 & 32.10 & 88.44 & 0.8844 \\
\hline & \multirow{4}{*}{$\mathrm{Br}^{-}$} & 10 & 17.18 & 70.31 & 0.7031 & 39.33 & 75.49 & 0.7549 & 51.08 & 81.60 & 0.8160 \\
\hline & & 20 & 12.21 & 78.91 & 0.7891 & 32.10 & 80.00 & 0.8000 & 36.62 & 86.81 & 0.8681 \\
\hline & & 40 & 9.49 & 83.59 & 0.8359 & 23.05 & 85.63 & 0.8563 & 27.57 & 90.07 & 0.9007 \\
\hline & & 60 & 7.23 & 87.50 & 0.8750 & 17.18 & 89.30 & 0.8930 & 15.37 & 94.46 & 0.9446 \\
\hline & \multirow{4}{*}{$\mathrm{I}^{-}$} & 10 & 8.13 & 85.94 & 0.8594 & 16.27 & 89.86 & 0.8364 & 18.53 & 93.53 & 0.9124 \\
\hline & & 20 & 6.32 & 89.06 & 0.8906 & 12.20 & 92.39 & 0.8773 & 14.46 & 94.95 & 0.9316 \\
\hline & & 40 & 4.06 & 92.97 & 0.9297 & 8.58 & 94.65 & 0.9136 & 10.39 & 96.37 & 0.9509 \\
\hline & & 60 & 2.71 & 95.31 & 0.9531 & 4.97 & 96.90 & 0.9500 & 5.87 & 97.95 & 0.9722 \\
\hline \multirow{12}{*}{4} & \multirow{4}{*}{$\mathrm{Cl}^{-}$} & 10 & 11.41 & 79.80 & 0.7980 & 68.94 & 68.81 & 0.6881 & 122.84 & 66.05 & 0.6605 \\
\hline & & 20 & 9.95 & 82.40 & 0.8240 & 54.36 & 75.41 & 0.7541 & 107.59 & 70.27 & 0.7027 \\
\hline & & 40 & 8.70 & 84.60 & 0.8460 & 36.05 & 83.69 & 0.8369 & 87.70 & 75.77 & 0.7577 \\
\hline & & 60 & 7.23 & 87.20 & 0.8720 & 32.21 & 85.43 & 0.8543 & 69.95 & 80.67 & 0.8067 \\
\hline & \multirow{4}{*}{$\mathrm{Br}^{-}$} & 10 & 10.06 & 82.20 & 0.8220 & 63.29 & 71.37 & 0.7137 & 114.93 & 68.24 & 0.6824 \\
\hline & & 20 & 8.36 & 85.20 & 0.8520 & 48.71 & 77.97 & 0.7797 & 104.20 & 71.21 & 0.7121 \\
\hline & & 40 & 7.80 & 86.20 & 0.8620 & 32.66 & 85.22 & 0.8522 & 80.92 & 77.64 & 0.7764 \\
\hline & & 60 & 6.44 & 88.60 & 0.8860 & 27.69 & 87.47 & 0.8747 & 64.30 & 82.23 & 0.8223 \\
\hline & \multirow{4}{*}{$\mathrm{I}^{-}$} & 10 & 8.93 & 84.20 & 0.8420 & 55.38 & 74.95 & 0.7495 & 123.18 & 65.96 & 0.6596 \\
\hline & & 20 & 7.23 & 87.20 & 0.8720 & 44.19 & 80.01 & 0.8001 & 98.55 & 72.77 & 0.7277 \\
\hline & & 40 & 6.67 & 88.20 & 0.8820 & 32.66 & 85.22 & 0.8522 & 79.90 & 77.92 & 0.7792 \\
\hline & & 60 & 5.31 & 90.60 & 0.9060 & 24.30 & 89.01 & 0.8901 & 55.26 & 84.73 & 0.8473 \\
\hline
\end{tabular}
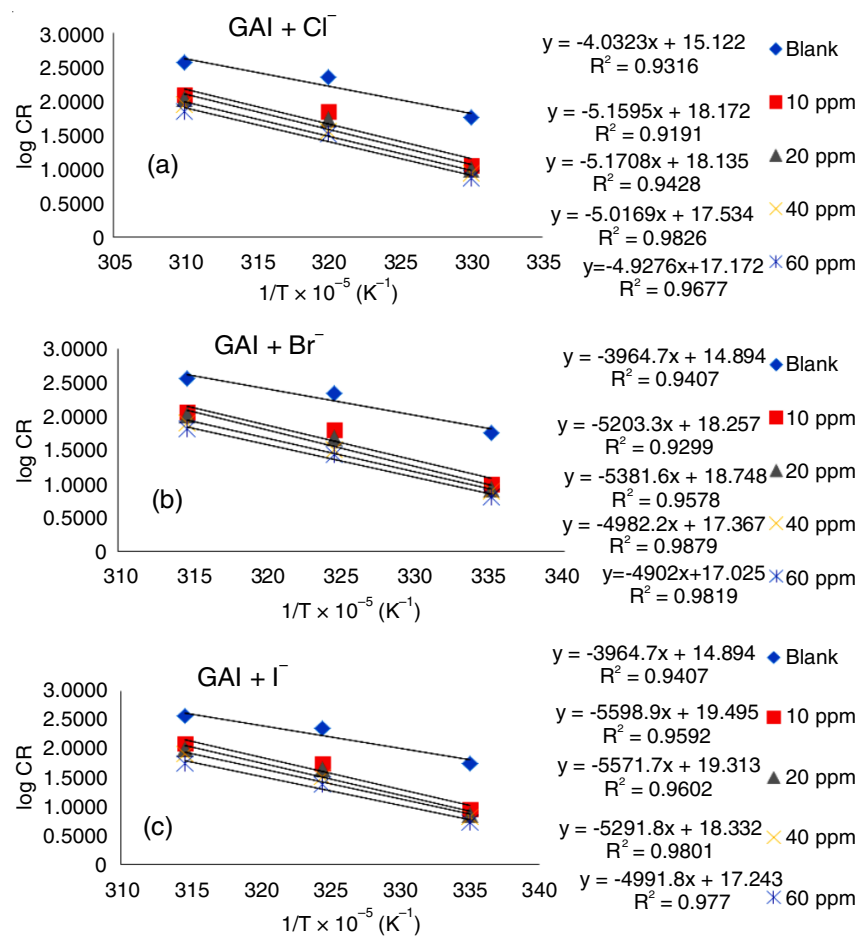

Fig. 2a-c. Arrhenius plots for $\mathrm{GAI}+\mathrm{X}^{-}$ion mixture on carbon steel in $1 \mathrm{~N}$ $\mathrm{H}_{2} \mathrm{SO}_{4}$ for $4 \mathrm{~h}$ immersion period

Eqn. 5, the alternative form of Arrhenius equation is used to attain the enthalpy and entropy of corrosion process.

$$
\mathrm{CR}=\left(\frac{\mathrm{RT}}{\mathrm{Nh}}\right) \exp \left(\frac{\Delta \mathrm{S}^{*}}{\mathrm{R}}\right) \exp \left(\frac{-\Delta \mathrm{H}^{*}}{\mathrm{RT}}\right)
$$

Figs. 3a-c and 4a-c shows the plots of CR/T vs. 1/T for immersion periods $1 \mathrm{~h}$ and $4 \mathrm{~h}$. These graphs gave straight line with slope $\left(-\Delta \mathrm{H}^{*} / 2.303 \mathrm{R}\right)$ and an intercept $\left(\log (\mathrm{R} / \mathrm{Nh})+\Delta \mathrm{S}^{*} /\right.$
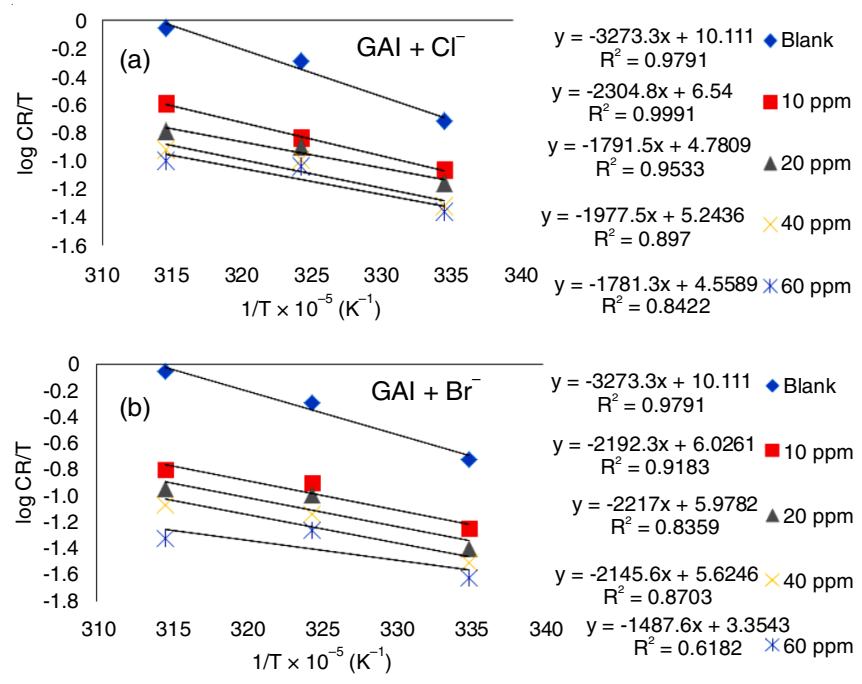

$$
\begin{gathered}
y=-3273.3 x+10.111 \text { Blank } \\
R^{2}=0.9791 \\
y=-2192.3 x+6.0261 \quad 10 p p m \\
R^{2}=0.9183 \\
y=-2217 x+5.9782 \backsim 20 p p m \\
R^{2}=0.8359 \\
y=-2145.6 x+5.6246 \quad 40 p p m \\
R^{2}=0.8703 \\
340 \quad y=-1487.6 x+3.3543 \\
R^{2}=0.6182 * 60 p p m
\end{gathered}
$$

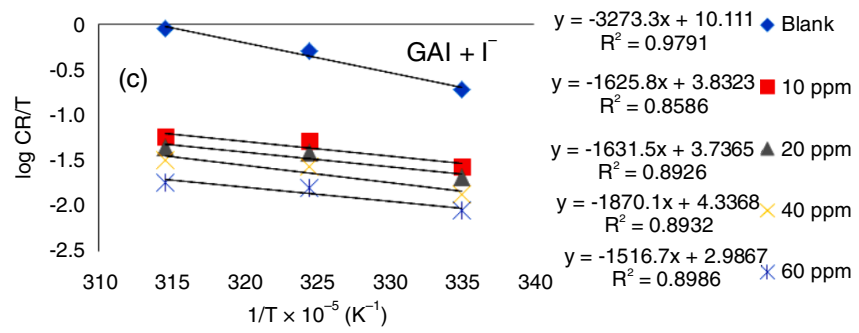

Fig. 3a-c. Transition plots for $\mathrm{GAI}+\mathrm{X}^{-}$ion mixture on carbon steel in $1 \mathrm{~N}$ $\mathrm{H}_{2} \mathrm{SO}_{4}$ for $1 \mathrm{~h}$ immersion period 

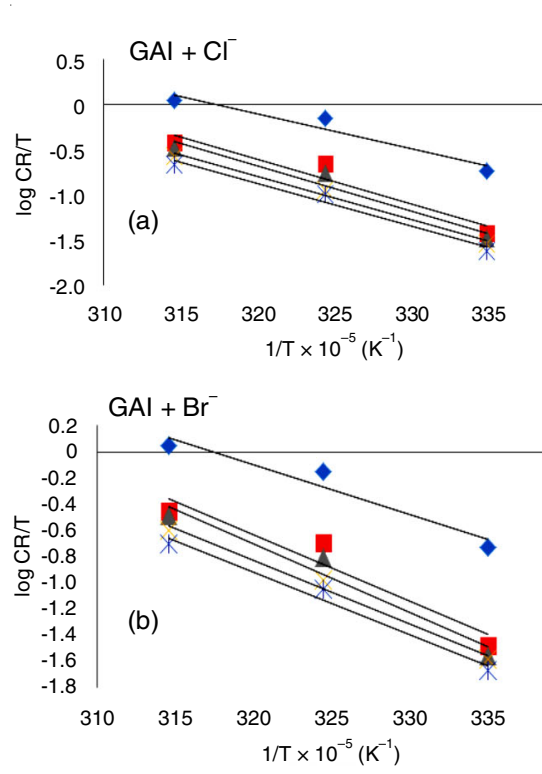

$y=-3828.9 x+11.964$ Blank $R^{2}=0.9365$

$\mathrm{y}=-5067.5 \mathrm{x}+15.327 \quad 10 \mathrm{ppm}$ $R^{2}=0.9262$

$y=-5245.8 x+15.818 \Delta 20 p p m$ $y=-4846.4 x+14.437$
$R^{2}=0.9871$$\quad 40 p p m$ $y=-4766.2 x+14.096600 p m$
$R^{2}=0.9808$ 340 $y=-3828.9 x+11.964$ Blank

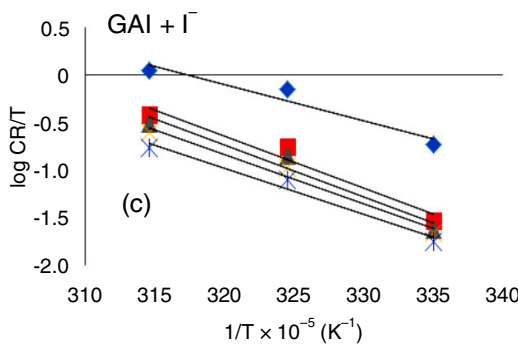

$y=-5463 x+16.565 \square 10 p p m$ $\mathrm{R}^{2}=0.9571$

$y=-5435.9 x+16.383 \backsim 20 p p m$ $R^{2}=0.9582$

$y=-5156 x+15.402 \times 40 p p m$

$y=-4856 x+14.314$
$R^{2}=0.9757$$* 60 p p m$

Fig. 4a-c. Transition plots for $\mathrm{GAI}+\mathrm{X}^{-}$ion mixture on carbon steel in $1 \mathrm{~N}$ $\mathrm{H}_{2} \mathrm{SO}_{4}$ for $4 \mathrm{~h}$ immersion period
$2.303 \mathrm{R})$, from which enthalpy $\left(\Delta \mathrm{H}^{*}\right)$ and entropy $\left(\Delta \mathrm{S}^{*}\right)$ of activation was obtained and those values were presented in Table-3.

Analysis of Table- 3 indicates that activation energy is lower in inhibited solutions than in uninhibited solutions. This decrease in $\mathrm{E}_{\mathrm{a}}$ value on addition of GAI-halide combination was ascribed to their chemisorption on carbon steel surface $[26,27]$. Enthalpy change $\left(\Delta \mathrm{H}^{*}\right)$ in presence of GAI-halide mixture found lesser compared to blank than the blank again established the chemical mode of adsorption. In addition, change in enthalpy values being positive reflects the endothermic nature of the corrosion process $[28,29]$. The values of $\Delta S^{*}$ for the uninhibited solution decreases towards more negative side with increase in concentration of GAI in the inhibitor system which depicts the increase in disorder as there would be conversion of reactants into activated complexes [30]. The calculated $\mathrm{E}_{\mathrm{a}}, \Delta \mathrm{H}^{*}$ and $\Delta \mathrm{S}$ values of the inhibitor mixtures for $4 \mathrm{~h}$ immersion time are presented in the Table-3. In contrast, for $4 \mathrm{~h}$ immersion period, the results obtained validate the physical mode of adsorption.

Adsorption isotherm gives information about inhibitor adsorption on the surface [31,32]. Various kinds of isotherms such as Langmuir, Frumkin, Freundlich, El-Awady and Temkin were tried for both $1 \mathrm{~h}$ and $4 \mathrm{~h}$ immersion time and Langmuir is found to be the best fit isotherm. Figs. 5a-c shows the Langmuir plots for $1 \mathrm{~h}$ immersion time. Accordingly concentration (C), equilibrium constant $\left(\mathrm{K}_{\mathrm{ads}}\right)$ and surface coverage $(\theta)$ is related as:

$$
\mathrm{C} / \theta=1 / \mathrm{K}_{\mathrm{ads}}+\mathrm{C}
$$

Correlation coefficient values $\left(\mathrm{R}^{2}>0.99\right)$ were suggestive of the phenomenon that the adsoption process obeyed

TABLE-3

ACTIVATION PARAMETERS OBTAINED FROM WEIGHT LOSS MEASUREMENTS FOR CARBON STEEL IN $1 \mathrm{~N} \mathrm{H}_{2} \mathrm{SO}_{4}$ SOLUTION CONTAINING VARIOUS CONCENTRATIONS OF GAI IN THE PRESENCE OF HALIDE IONS

\begin{tabular}{|c|c|c|c|c|c|c|}
\hline $\begin{array}{l}\text { Immersion } \\
\text { period }(\mathrm{h})\end{array}$ & $\begin{array}{c}\text { Halide ion } \\
\text { concentration }(1 \mathrm{mM})\end{array}$ & $\begin{array}{c}\text { Concentration of } \\
\text { GAI (ppm) }\end{array}$ & $\mathrm{E}_{\mathrm{a}}\left(\mathrm{kJ} \mathrm{mol}^{-1}\right)$ & $\Delta \mathrm{H}\left(\mathrm{kJ} \mathrm{mol}^{-1}\right)$ & $\Delta \mathrm{S}\left(\mathrm{J} \mathrm{K}^{-1} \mathrm{~mol}^{-1}\right)$ & $\mathrm{E}_{\mathrm{a}}-\Delta \mathrm{H}$ \\
\hline \multirow{13}{*}{1} & \multirow{5}{*}{$\mathrm{Cl}^{-}$} & Blank & 66.5247 & 63.8671 & -11.292 & 2.6 \\
\hline & & 10 & 47.7743 & 45.1167 & -80.389 & 2.6 \\
\hline & & 20 & 37.5628 & 34.9052 & -115.322 & 2.6 \\
\hline & & 40 & 41.1039 & 38.4463 & -106.520 & 2.6 \\
\hline & & 60 & 37.2278 & 34.5702 & -120.020 & 2.6 \\
\hline & \multirow{4}{*}{$\mathrm{Br}^{-}$} & 10 & 45.3112 & 42.6536 & -91.220 & 2.6 \\
\hline & & 20 & 45.6775 & 43.019 & -92.481 & 2.6 \\
\hline & & 40 & 44.3362 & 41.6786 & -99.173 & 2.6 \\
\hline & & 60 & 31.3399 & 28.6823 & -143.951 & 2.6 \\
\hline & \multirow{4}{*}{$\mathrm{I}^{-}$} & 10 & 34.2266 & 31.5689 & -134.019 & 2.6 \\
\hline & & 20 & 34.3712 & 31.7136 & -135.737 & 2.6 \\
\hline & & 40 & 39.0109 & 36.3532 & -124.004 & 2.6 \\
\hline & & 60 & 32.1473 & 29.4896 & -150.188 & 2.6 \\
\hline \multirow{13}{*}{4} & \multirow{5}{*}{$\mathrm{Cl}^{-}$} & Blank & 77.2061 & 74.5485 & 24.356 & 2.6 \\
\hline & & 10 & 98.7904 & 96.1328 & 82.767 & 2.6 \\
\hline & & 20 & 99.00549 & 96.3478 & 82.047 & 2.6 \\
\hline & & 40 & 96.0584 & 93.4008 & 70.542 & 2.6 \\
\hline & & 60 & 94.34854 & 91.6909 & 63.619 & 2.6 \\
\hline & \multirow{4}{*}{$\mathrm{Br}^{-}$} & 10 & 101.2818 & 98.6241 & 89.967 & 2.6 \\
\hline & & 20 & 104.8784 & 102.2208 & 99.967 & 2.6 \\
\hline & & 40 & 97.2736 & 94.6159 & 73.629 & 2.6 \\
\hline & & 60 & 95.6627 & 93.0050 & 66.850 & 2.6 \\
\hline & \multirow{4}{*}{$\mathrm{I}^{-}$} & 10 & 109.1195 & 106.4619 & 114.540 & 2.6 \\
\hline & & 20 & 108.5965 & 105.9389 & 111.039 & 2.6 \\
\hline & & 40 & 103.2574 & 100.5998 & 92.309 & 2.6 \\
\hline & & 60 & 97.38342 & 94.7258 & 71.040 & 2.6 \\
\hline
\end{tabular}



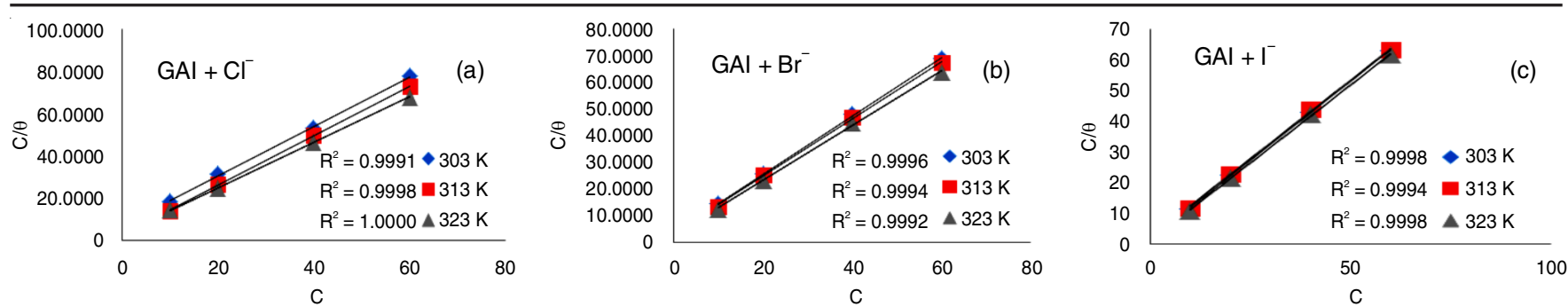

Fig. 5a-c. Langmuir adsorption isotherm plots for GAI with halide ions for $1 \mathrm{~h}$ immersion period

Langmuir model. Equilibrium constant and free energy of $\operatorname{adsorption}\left(\Delta \mathrm{G}^{\circ}\right)$ is related as:

$$
\mathrm{K}=-\log \mathrm{C}_{\mathrm{H}_{2} \mathrm{O}}-\left(\frac{\Delta \mathrm{G}_{\mathrm{ads}}^{\mathrm{o}}}{2.303 \mathrm{RT}}\right)
$$

The negative $\Delta \mathrm{G}_{\text {ads }}^{\circ}$ shown in the Table- 4 indicates that a spontaneous adsorption of GAI + halide ion mixture took place with strong interaction on carbon steel surface [33]. Investigation of the experimental results indicates that the inhibitor system adsorbed chemically for $1 \mathrm{~h}$ immersion time and physically for $4 \mathrm{~h}$ immersion time.

Synergistic effect: Synergistic corrosion inhibition is a proficient approach to enhance the performance ability of inhibitors in terms of quantity and varied utility. The combined action of compounds in total giving higher effect than the individual effect is called synergistic inhibition effect. Synergistic studies of organic compounds with halides have been extensively studied [21,34-36]. Addition of halides to corrosive media enhances the adsorption capacity of the inhibitors by bridging between inhibitor cations and negatively charged metal surface. Synergistic effect using iodide ion excelled compared to that of chloride and bromide ions. This is attributed to the fact that iodide ions has ionic radius, polarizability and hydrophobicity higher than bromide and chloride ions $[37,38]$.

Determination of extent of synergistic influence i.e. synergism parameter can be obtained from eqn. 8 :

$$
S=\frac{1-\left(\eta_{1}+\eta_{2}\right)}{1-\eta_{1+2}}
$$

where $\eta_{1}, \eta_{2}$ are the inhibition efficiencies of GAI and halide ions respectively and $\eta_{1+2}$ is the combined efficiency of the inhibitor mixtures.

Addition of halide ion with GAI showed very high inhibition efficiency than that in the absence of halides. This reflects that there was synergism exhibiting between the halide ions and GAI in $1 \mathrm{~N}$ sulphuric acid medium for carbon steel corrosion control from which it was understood that strong chemical adsorption of halide ions on carbon steel surface [39]. When the halide ions get into the double layer of the metallic substrate, the charge of the halide befits the charge of the carbon steel surface $[40,41]$. So coulombic attraction plays the role in adsorption process. On stabilization of adsorbed halide ions, better surface coverage is possible so that greater inhibition performance is effected [42]. The synergistic mechanism may be either competitive or cooperative [43]. Competitive adsorption is one where cations of the inhibitor is adsorbed at various metal sites while in co-operative adsorption anions are chemisorbed on metal substrate and the cations on anion layers. There are some cases where both mechanisms operate occur simultaneously [19]. Generally, $\mathrm{S}<1$ denotes antagonistic effect while $S>1$ denotes synergistic behaviour [44]. Most of the values of $S>1$ presented in Table- 5 reveals that there pre vailed synergism between GAI and halide ions for carbon steel corrosion control in sulphuric acid. Some values $\mathrm{S}<1$ is also observed.

Potentiodynamic polarization studies: Anodic and cathodic polarization curves with and without inhibitor for

TABLE-4

LANGMUIR ADSORPTION PARAMETERS FOR MILD STEEL CORROSION IN $\mathrm{H}_{2} \mathrm{SO}_{4}$

\begin{tabular}{|c|c|c|c|c|c|}
\hline Immersion period $(\mathrm{h})$ & $\mathrm{X}^{-}(1 \mathrm{mM})$ & Temperature $(\mathrm{K})$ & $\mathrm{R}^{2}$ & Slope & $\Delta \mathrm{G}_{\mathrm{ads}}(\mathrm{kJ} / \mathrm{mol})$ \\
\hline \multirow{9}{*}{1} & \multirow{3}{*}{$\mathrm{Cl}^{-}$} & 303 & 0.999 & 1.1707 & -34.1700 \\
\hline & & 313 & 0.999 & 1.1739 & -37.8300 \\
\hline & & 323 & 1.000 & 1.0751 & -38.4400 \\
\hline & \multirow{3}{*}{$\mathrm{Br}^{-}$} & 303 & 0.999 & 1.0900 & -35.9200 \\
\hline & & 313 & 0.999 & 1.0763 & -36.3100 \\
\hline & & 323 & 0.999 & 1.0278 & -36.9200 \\
\hline & \multirow{3}{*}{$\mathrm{I}^{-}$} & 303 & 0.999 & 1.0246 & -37.9030 \\
\hline & & 313 & 0.999 & 1.0245 & -37.1270 \\
\hline & & 323 & 0.999 & 1.0154 & -38.9730 \\
\hline \multirow{9}{*}{4} & \multirow{3}{*}{$\mathrm{Cl}^{-}$} & 303 & 0.999 & 1.1264 & -20.5158 \\
\hline & & 313 & 0.999 & 1.1060 & -18.9482 \\
\hline & & 323 & 0.999 & 1.1830 & -19.2732 \\
\hline & \multirow{3}{*}{$\mathrm{Br}^{-}$} & 303 & 0.999 & 1.1140 & -21.1900 \\
\hline & & 313 & 0.999 & 1.0863 & -19.1900 \\
\hline & & 323 & 0.999 & 1.1608 & -19.3800 \\
\hline & \multirow{3}{*}{$\mathrm{I}^{-}$} & 303 & 0.999 & 1.0898 & -21.3100 \\
\hline & & 313 & 0.999 & 1.0801 & -19.5200 \\
\hline & & 323 & 0.999 & 1.1171 & -18.8900 \\
\hline
\end{tabular}
CONTAINING VARIOUS CONCENTRATIONS OF GAI IN PRESENCE OF $1 \mathrm{mM}$ of $\mathrm{X}^{-}$IONS 


\begin{tabular}{|c|c|c|c|c|c|}
\hline \multicolumn{6}{|c|}{$\begin{array}{c}\text { TABLE-5 } \\
\text { SYNERGISTIC PARAMETERS FOR DIFFERENT } \\
\text { CONCENTRATIONS OF GAI WITH } 1 \mathrm{mM} \text { OF HALIDE IONS }\end{array}$} \\
\hline \multirow{2}{*}{$\begin{array}{l}\text { Immersion } \\
\text { period }(\mathrm{h})\end{array}$} & \multicolumn{2}{|c|}{ Concentration } & \multicolumn{3}{|c|}{ Synergistic parameter } \\
\hline & $\begin{array}{c}\mathrm{X}^{-} \\
(1 \mathrm{mM})\end{array}$ & $\begin{array}{c}\text { GAI } \\
\text { (ppm) }\end{array}$ & $303 \mathrm{~K}$ & $313 \mathrm{~K}$ & $323 \mathrm{~K}$ \\
\hline \multirow{12}{*}{1} & \multirow{4}{*}{$\mathrm{Cl}^{-}$} & 10 & 1.51 & 1.17 & 1.01 \\
\hline & & 20 & 1.40 & 1.20 & 1.00 \\
\hline & & 40 & 1.27 & 1.18 & 1.01 \\
\hline & & 60 & 1.28 & 1.15 & 0.99 \\
\hline & \multirow{4}{*}{$\mathrm{Br}^{-}$} & 10 & 1.59 & 0.88 & 1.31 \\
\hline & & 20 & 1.49 & 1.00 & 1.35 \\
\hline & & 40 & 1.49 & 1.07 & 1.36 \\
\hline & & 60 & 1.46 & 1.06 & 1.31 \\
\hline & \multirow{4}{*}{$\mathrm{I}^{-}$} & 10 & 1.53 & 1.01 & 1.36 \\
\hline & & 20 & 1.55 & 1.14 & 1.45 \\
\hline & & 40 & 1.56 & 1.23 & 1.48 \\
\hline & & 60 & 1.56 & 1.23 & 1.47 \\
\hline \multirow{12}{*}{4} & \multirow{4}{*}{$\mathrm{Cl}^{-}$} & 10 & 1.03 & 0.97 & 1.02 \\
\hline & & 20 & 1.03 & 1.03 & 1.03 \\
\hline & & 40 & 1.03 & 1.09 & 1.11 \\
\hline & & 60 & 1.03 & 1.10 & 1.15 \\
\hline & \multirow{4}{*}{$\mathrm{Br}^{-}$} & 10 & 1.16 & 1.12 & 1.07 \\
\hline & & 20 & 1.15 & 1.17 & 1.07 \\
\hline & & 40 & 1.15 & 1.21 & 1.15 \\
\hline & & 60 & 1.15 & 1.22 & 1.19 \\
\hline & \multirow{4}{*}{$\mathrm{I}^{-}$} & 10 & 1.19 & 0.99 & 0.93 \\
\hline & & 20 & 1.18 & 1.08 & 0.97 \\
\hline & & 40 & 1.16 & 1.20 & 1.08 \\
\hline & & 60 & 1.16 & 1.20 & 1.15 \\
\hline
\end{tabular}

carbon steel in $1 \mathrm{~N}$ sulphuric acid solution were depicted in Fig. 6. These curves on extrapolation was used to obtain corrosion current density and corrosion potential. Using corrosion current density with $\left(\mathrm{i}_{\text {corr }}\right)$ and without $\left(\mathrm{i}_{\text {corr }}^{\circ}\right)$ the inhibitor, efficiency of the inhibitor can be calculated using eqn. 9:

$$
\text { Inhibition efficiency }=\frac{i_{\text {corr }}^{o}-i_{\text {corr }}}{i_{\text {corr }}} \times 100
$$

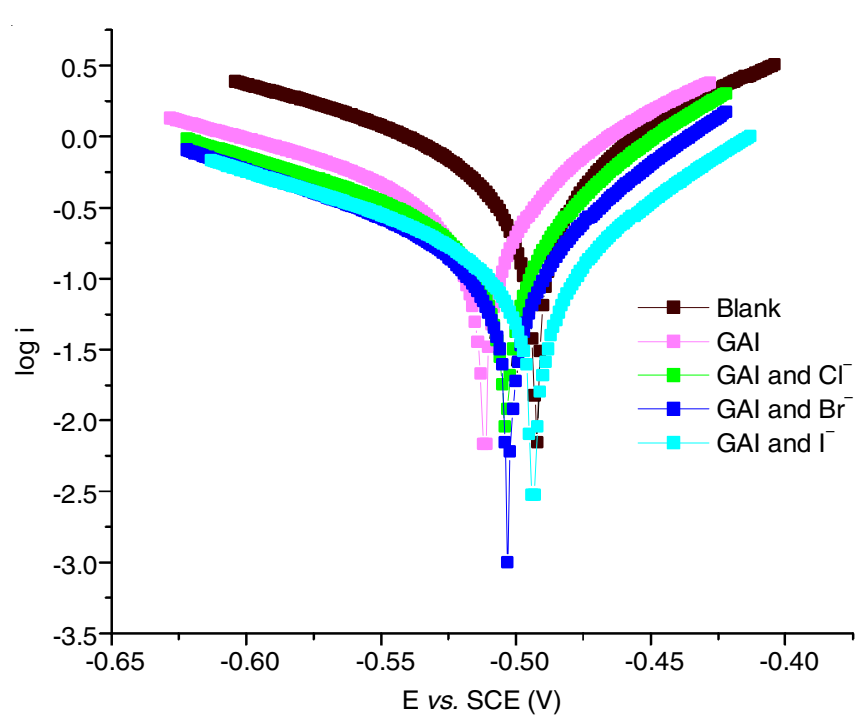

Fig. 6. Potentiodynamic polarization curves for carbon steel in the absence and presence of inhibitor mixtures

The inhibition efficiency calculated using expression (eqn. 9 ), the electrochemical polarization factors $\mathrm{E}_{\text {corr }}, \mathrm{I}_{\text {corr }}$, anodic and cathodic tafel slopes were listed in Table-6. Fig. 6 reflects that upon the addition of GAI and GAI + halide mixture to $1 \mathrm{~N} \mathrm{H}_{2} \mathrm{SO}_{4}$ solution, slope of both anodic and cathodic curves changed. The results obtained depicted the impedance in hydrogen evolution at the cathode and metal dissolution at the anode. So it could be understood that GAI and GAI-halide mixture affected cathodic as well as anodic reactions. Table- 6 shows that the presence of inhibitors reduces the corrosion current density indicating that inhibitor get absorbed onto the metal surface. Since there is not much change in the nature of the polarization curves, it was assumed that the inhibitor system hinder the deterioration reaction through the same mechanism. A small change in the value of $E_{\text {corr }}$ in comparison with and without inhibitor indicated the mixed mode type of inhibitor [45]. The maximum difference was found to be $23 \mathrm{mV}$, which indicates that the inhibitors possibly will be of mixed type $[46,47]$. This fact is supported by the behaviour of Tafel slopes $b_{a}$ and $b_{c}$ also. Addition of halide ions to GAI decreased the corrosion current thereby increasing the inhibitor efficiency. In particular addition of iodide ions decrease the $\mathrm{I}_{\text {corr }}$ value from 410 to $103 \mathrm{~mA} / \mathrm{cm}^{2}$ owing to its strong chemical adsorption increasing the mitigation perfor-mance in aggressive solution [48]. The following order of inhibitor mixture performance is observed:

$$
\mathrm{GAI}+\mathrm{KI}>\mathrm{GAI}+\mathrm{KBr}>\mathrm{GAI}+\mathrm{KCl}
$$

\section{TABLE-6}

ELECTROCHEMICAL POLARIZATION PARAMETERS FOR CARBON STEEL IN $1 \mathrm{~N} \mathrm{H}_{2} \mathrm{SO}_{4}$ IN THE ABSENCE AND

\begin{tabular}{|c|c|c|c|c|c|}
\hline \multirow{2}{*}{$\begin{array}{l}\text { Concentration } \\
\text { (ppm) }\end{array}$} & \multirow{2}{*}{$\begin{array}{l}-E_{\text {corr }} \\
(V v s . \\
\text { SCE) }\end{array}$} & \multirow{2}{*}{$\begin{array}{l}\mathrm{I}_{\text {corr }} \\
(\mathrm{mA} / \\
\left.\mathrm{cm}^{2}\right)\end{array}$} & \multicolumn{2}{|c|}{$\begin{array}{c}\text { Tafel slope } \\
\text { (mV/decade) }\end{array}$} & \multirow{2}{*}{$\begin{array}{l}\text { Inhibition } \\
\text { efficiency } \\
(\%)\end{array}$} \\
\hline & & & $\mathrm{b}_{\mathrm{a}}$ & $\mathrm{b}_{\mathrm{c}}$ & \\
\hline Blank & 490.1 & 410 & 85 & 137 & - \\
\hline GAI & 513.6 & 201 & 74 & 160 & 55.60 \\
\hline $\mathrm{GAI}+\mathrm{Cl}^{-}$ion & 496.3 & 164 & 64 & 154 & 60.00 \\
\hline $\mathrm{GAI}+\mathrm{Br}^{-}$ion & 495.5 & 114 & 62 & 143 & 72.19 \\
\hline $\mathrm{GAI}+\mathrm{I}^{-}$ion & 485.7 & 103 & 69 & 149 & 74.87 \\
\hline
\end{tabular}
PRESENCE OF 60 ppm GAI AND 1 mM HALIDE MIXTURES

Electrochemical impedance measurements: Fig. 7 shows the Nyquist plots from which the impedance data for carbon steel in $1 \mathrm{~N}$ sulphuric acid without, with $60 \mathrm{ppm}$ GAI in the presence and absence of halide ions in the presence and absence of halide ions was given in Table-7. Data describes the single, depressed semicircles shows presence of GAI and GAI-mixture was not affecting the corrosion mechanism process and in addition the charge transfer process undertakes completely the corrosion process [49]. Using charge transfer values with $\left(\mathrm{R}_{\mathrm{ct}}\right)$ and without $\left(\mathrm{R}^{\circ}{ }_{\mathrm{ct}}\right)$ inhibitor, inhibition efficiency was calculated as follows:

$$
\text { Inhibition efficiency }=\frac{\mathrm{R}_{\mathrm{ct}}-\mathrm{R}_{\mathrm{ct}}^{\mathrm{o}}}{\mathrm{R}_{\mathrm{ct}}} \times 100
$$

Inhibition efficiency obtained from eqn. 10, charge transfer resistance and double layer capacitance were shown in the Table-7. The double layer capacitance $\left(\mathrm{C}_{\mathrm{dl}}\right)$ can be calculated from the expression (eqn. 11) which is related to charge transfer resistance and frequency $f_{\max }$ as:

$$
C_{\mathrm{dl}}=1 / 2 \pi f_{\max } R_{c t}
$$




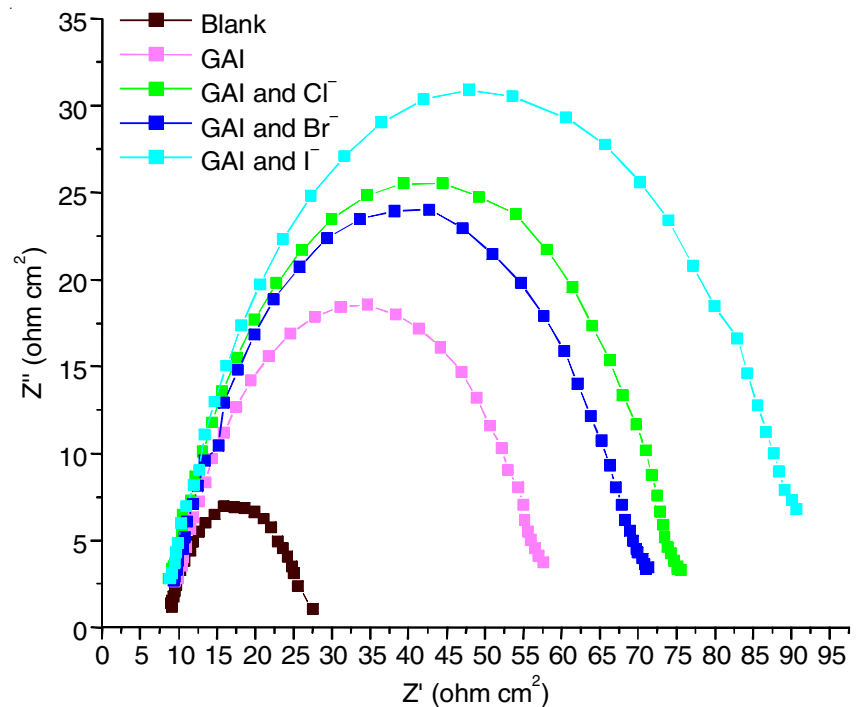

Fig. 7. Nyquist plots for carbon steel in the absence and presence of inhibitor mixtures

TABLE-7

AC IMPEDANCE PARAMETERS FOR CARBON STEEL IN $1 \mathrm{~N} \mathrm{H}_{2} \mathrm{SO}_{4}$ IN THE ABSENCE AND PRESENCE OF $60 \mathrm{ppm}$ GAI AND 1 mM HALIDE MIXTURES

\begin{tabular}{lccc}
\hline $\begin{array}{c}\text { Concentration } \\
(\mathrm{ppm})\end{array}$ & $\mathrm{R}_{\mathrm{ct}}\left(\Omega \mathrm{cm}^{-2}\right)$ & $\begin{array}{c}\mathrm{C}_{\mathrm{dl}}\left(\mu \mathrm{F} \mathrm{cm}^{-2}\right) \\
\times 10^{-3}\end{array}$ & $\begin{array}{c}\text { Inhibition } \\
\text { efficiency }(\%)\end{array}$ \\
\hline Blank & 19.19 & 35.1 & - \\
$60 \mathrm{ppm}$ GAI & 48.4 & 14.1 & 60.35 \\
$\mathrm{GAI}+\mathrm{Cl}^{-}$ion & 51.2 & 13.9 & 62.51 \\
$\mathrm{GAI}+\mathrm{Br}^{-}$ion & 68.8 & 13.2 & 72.10 \\
$\mathrm{GAI}+\mathrm{I}^{-}$ion & 89.5 & 12.3 & 78.56 \\
\hline
\end{tabular}

Actually $R_{c t}$ is a measure of electron transfer and it can be seen that $R_{c t}$ value increased considerably for test solutions containing halide ions along with the inhibitor owing to the development of thin film of protective layer at the metal-solution interface [50]. In general, the double layer formed was considered like capacitor, where in presence of inhibitor the electrical capacity of the double layer decreases. This may be due to the displacement of water molecules and other adsorbed molecules. This fact leads to the formation of insulating protective layer which increases the thickness of the double layer. From the Table-7, it can be found that the $\mathrm{C}_{\mathrm{dl}}$ value of uninhibited solution is higher compared to inhibited solutions. Addition of GAI lowers the $\mathrm{C}_{\mathrm{dl}}$ from $35.1 \times 10^{-3}$ to $14.1 \times 10^{-3}$ $\mu \mathrm{F} \mathrm{cm} \mathrm{cm}^{-2}$ whereas addition of halide ions to GAI caused subsequent decrease in $\mathrm{C}_{\mathrm{dl}}$ up to $12.3 \times 10^{-3} \mu \mathrm{F} \mathrm{cm}^{-2}$ which increases the thickness of double layer. $R_{c t}$ was maximum for $60 \mathrm{ppm}$ $\mathrm{GAI}+1 \mathrm{mM}$ KI mixture. The order of inhibition performance was $\mathrm{GAI}+\mathrm{KI}>\mathrm{GAI}+\mathrm{KBr}>\mathrm{GAI}+\mathrm{KCl}$.

Scanning electron microscopy: Figs. 8(a)-8(f) show sthe SEM images of carbon steel coupons before and after immersion in sulphuric acid solution with and without GAI and GAI + halide mixture. Fig. 8(a) exemplifies the polished surface of the carbon steel specimen before immersion in the aggressive medium, while Fig. 8(b) represents the effect of $1 \mathrm{~N} \mathrm{H}_{2} \mathrm{SO}_{4}$ solutions on the carbon steel specimen after $1 \mathrm{~h}$ immersion which clearly shows large rough pits and corrosion products due to acid attack. On assessing the Figs. 8(c-f) which represents the SEM images of carbon steel specimen in the presence of GAI and GAI-halide mixture, it can be seen that corrosive effect is greatly reduced because of the presence of GAI and inhibitor

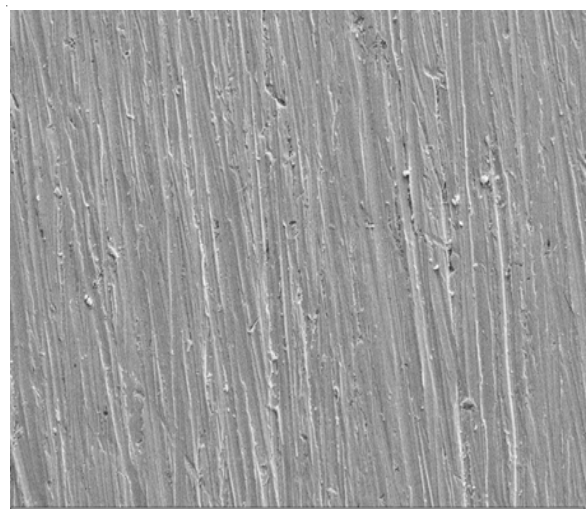

(a) Polished surface

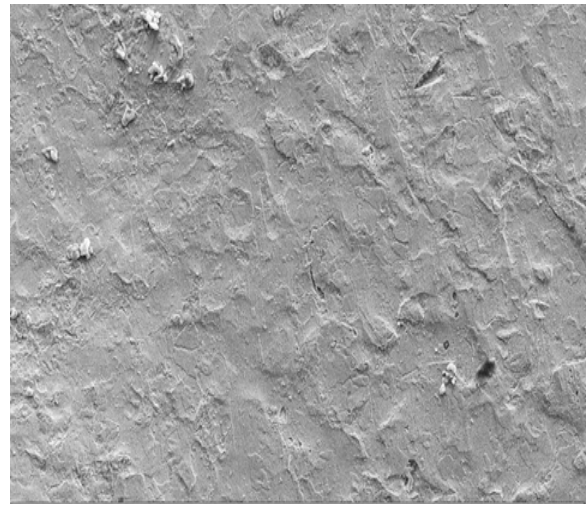

(d) in $60 \mathrm{ppm} \mathrm{GAI}$ and $\mathrm{Cl}^{-}$mixture

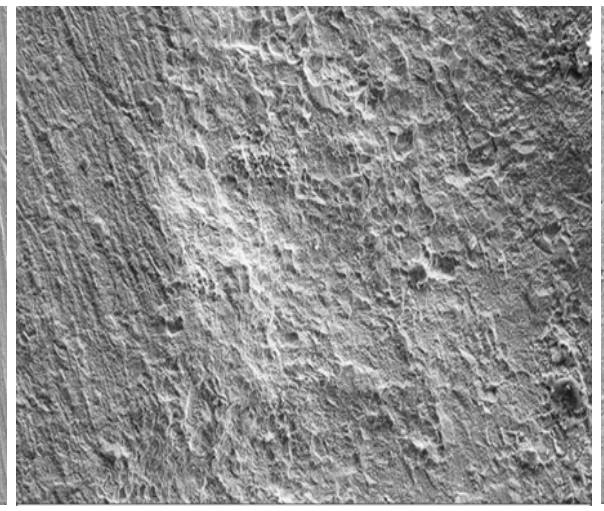

(b) After immersion in $1 \mathrm{~N} \mathrm{H}_{2} \mathrm{SO}_{4}$ solution

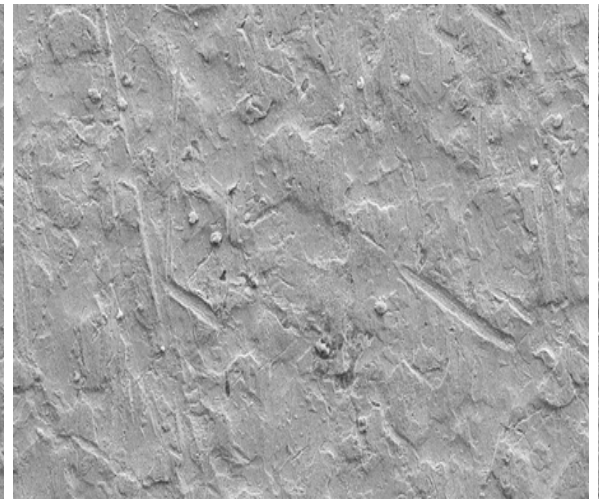

(e) in $60 \mathrm{ppm} \mathrm{GAI}$ and $\mathrm{Br}^{-}$mixture

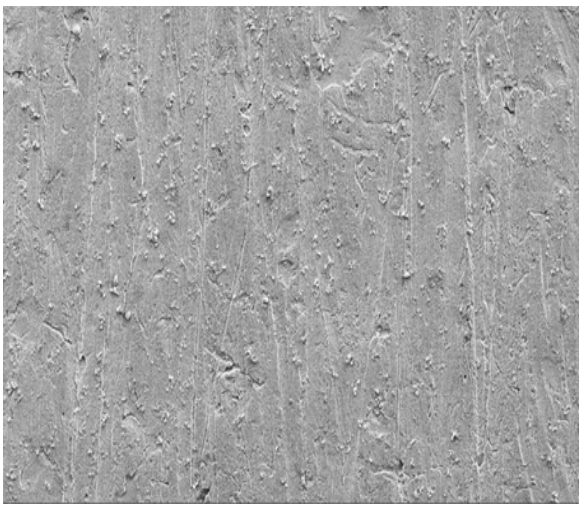

(c) in $60 \mathrm{ppm}$ GAl

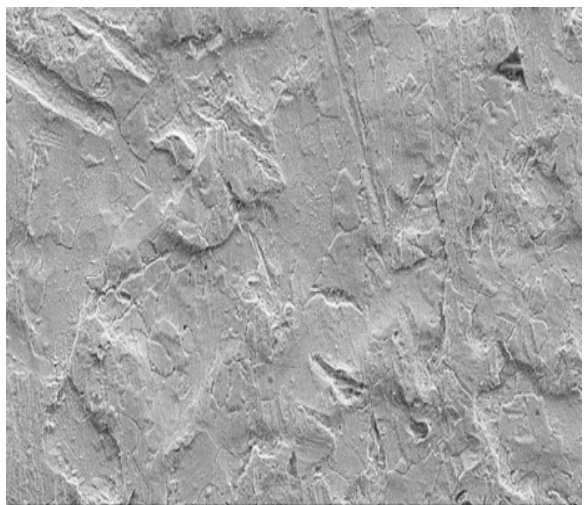

(f) in $60 \mathrm{ppm}$ GAI and I mixture

Fig. 8. SEM photographs of carbon steel sample 
mixture adsorbed layer. Especially in presence of halide ions very compact, rough, porous, crack-free protective layer and products due to corrosion were produced over carbon steel substrate, which reduces the rate of corrosion to a greater extent. Thus GAI addition along with halide ions in aggressive medium has controlled the process of corrosion for carbon steel specimen in $1 \mathrm{~N} \mathrm{H}_{2} \mathrm{SO}_{4}$ solution. The results obtained from the scanning electron micrographs are consistent with the fact that the mechanism of corrosion inhibition was adsorption.

\section{Conclusion}

- Synergistic influence of halides on GAI was found in the temperature range from 303 to $323 \mathrm{~K}$ for carbon steel in sulphuric acid.

- The performance order was observed as follows:

$$
\mathrm{GAI}+\mathrm{KI}>\mathrm{GAI}+\mathrm{KBr}>\mathrm{GAI}+\mathrm{KCl}
$$

- Polarization measurements exhibit mixed type of inhibitor.

- Adsorption type is chemical at $1 \mathrm{~h}$ and physical for $4 \mathrm{~h}$ immersion time.

-Adsorption mechanism was supported by SEM studies.

\section{REFERENCES}

1. D. Dwivedi, K. Lepkova and T. Becker, RSC Adv., 7, 4580 (2017); https://doi.org/10.1039/C6RA25094G.

2. S.A. Umoren, Cellulose, 15, 751 (2008); https://doi.org/10.1007/s10570-008-9226-4.

3. A. Jano, A. Lame and E. Kokalari, Kem. Ind.., 61, 497 (2012).

4. M. Abdallah, Port. Electrochim. Acta, 22, 161 (2004); https://doi.org/10.4152/pea.200402161.

5. N.O.Eddy, S.E. Abechi, P. Ameh and E.E. Ebenso, Walailak J. Sci. Technol, 10, 247 (2013)

6. S.A. Umoren, I.B. Obot, E.E. Ebenso and N.O. Obi-Egbedi, Desalination, 247, 561 (2009); https://doi.org/10.1016/j.desal.2008.09.005.

7. S.A. Umorena, I.B. Obota, E.E. Ebensob and N. Obi-Egbedi, Port. Electrochim. Acta, 26, 199 (2008);

https://doi.org/10.4152/pea.200802199.

8. P.O. Ameh, L. Magaji and T. Salihu, Afr. J. Pure Appl. Chem., 6, 100 (2012).

9. O.A. Paul, Int. J. Phys. Sci., 9, 184 (2014); https://doi.org/10.5897/IJPS2014.4116.

10. N.O. Eddy, P.O. Ameh and A.O. Odiongenyi, Port. Electrochim. Acta, 32, 183 (2014); https://doi.org/10.4152/pea.201403183.

11. P.O. Ameh, A.O. Odiongenyi and N.O. Eddy, Port. Electrochim. Acta, 30, 235 (2012); https://doi.org/10.4152/pea.201204235.

12. P.O. Ameh and N.O. Eddy, Res. Chem. Intermed., 40, 2641 (2014); https://doi.org/10.1007/s11164-013-1117-0.

13. N.O. Eddy, P.O. Ameh and E.E. Ebenso, Int. J. Electrochem. Sci., 7, 5677 (2012).

14. N.O. Eddy, P.O. Ameh, M.Y. Gwarzo, I.J. Okop and S.N. Dodo, Port. Electrochim. Acta, 31, 79 (2013); https://doi.org/10.4152/pea.201302079.

15. N.O. Eddy, U.J. Ibok, P.O. Ameh, N.O. Alobi and M.M. Sambo, Chem. Eng. Commun., 201, 1360 (2014); https://doi.org/10.1080/00986445.2013.809000.

16. P.O. Ameh, Int. J. Modern Chem., 2, 28 (2012).

17. N.O. Eddy, P.O. Ameh, O.O. Anduang and V. Emaikwu, Int. J. Chem. Mater. Environ. Res., 1, 3 (2014).

18. N.O. Eddy, P.O. Ameh, O.O. Anduang and E.E. Ebenso, Int. J. Electrochem. Sci., 7, 7425 (2012).

19. Q. Qu, Z. Hao, S. Jiang, L. Li and W. Bai, Mater. Corros., 59, 883 (2008); https://doi.org/10.1002/maco.200804176.

20. N.O. Eddy, S.A. Odoemelam and A.O. Odiongenyi, J. Appl. Electrochem., 39, 849 (2009); https://doi.org/10.1007/s10800-008-9731-z.
21. S.A. Umoren, M.M. Solomon, I.I. Udosoro and A.P. Udoh, Cellulose, 17, 635 (2010); https://doi.org/10.1007/s10570-010-9409-7.

22. M. Manickam, D. Sivakumar, B. Thirumalairaj and M. Jaganathan, Adv. Phys. Chem., Article ID 5987528 (2016); https://doi.org/10.1155/2016/5987528.

23. S. Mukherjee and H.C. Srivastava, J. Am. Chem. Soc., 77, 422 (1955); https://doi.org/10.1021/ja01607a059.

24. D.M.W. Anderson and A. Hendrie, Carbohydr. Res., 20, 259 (1971); https://doi.org/10.1016/S0008-6215(00)81379-8.

25. ASTM Practice Standard G-31, Standard Practice for Laboratory Immersion Corrosion Testing of Metals, ASTM International (2004).

26. K.O. Orubite and N.C. Oforka, J. Mater. Lett., 58, 1768 (2004); https://doi.org/10.1016/j.matlet.2003.11.030.

27. A.Y. El-Etre, J. Appl. Surf. Sci., 252, 8521 (2006); https://doi.org/10.1016/j.apsusc.2005.11.066.

28. E.E. Mola, Electrochim. Acta, 26, 1209 (1981); https://doi.org/10.1016/0013-4686(81)85101-8.

29. M. Dahmani, A. Et-Touhami, S.S. Al-Deyab, B. Hammouti and A. Bouyanzer, Int. J. Electrochem. Sci., 5, 1060 (2010).

30. V. Ramesh Saliyan and A.V. Adhikari, Bull. Mater. Sci., 31, 699 (2007); https://doi.org/10.1007/s12034-008-0111-4.

31. L. Bammou, M. Belkhaouda, R. Salghi, O. Benali, A. Zarrouk, H. Zarrok and B. Hammouti, J. Assoc. Arab. Univ. Basic Appl. Sci., 16, 83 (2014); https://doi.org/10.1016/j.jaubas.2013.11.001.

32. M. Lebrini, F. Robert and C. Roos, Int. J. Electrochem. Sci., 5, 1698 (2010).

33. S.A. Ali, M.T. Saeed and S.U. Rahman, Corros. Sci., 45, 253 (2003); https://doi.org/10.1016/S0010-938X(02)00099-9.

34. E.E. Ebenso, Mater. Chem. Phys., 79, 58 (2003); https://doi.org/10.1016/S0254-0584(02)00446-7.

35. S.A. Umoren and U.F. Ekanem, Chem. Eng. Commun., 197, 1339 (2010); https://doi.org/10.1080/00986441003626086.

36. I.B. Obot, N.O. Obi-Egbedi and S.A. Umoren, Corros. Sci., 51, 276 (2009); https://doi.org/10.1016/j.corsci.2008.11.013.

37. G.N. Mu, X.M. Li and F. Li, Mater. Chem. Phys., 86, 59 (2004); https://doi.org/10.1016/j.matchemphys.2004.01.041.

38. X. Li, S. Deng, H. Fu and G. Mu, Corros. Sci., 52, 1167 (2010); https://doi.org/10.1016/j.corsci.2009.12.017.

39. S.A. Umoren, O. Ogbobe, I.O. Igwe and E.E. Ebenso, Corros. Sci., 50, 1998 (2008); https://doi.org/10.1016/j.corsci.2008.04.015.

40. A.G. Maitra Singh and B.B. Chakraborty, Trans. Soc. Adv. Electrochem. Sci. Technol., 18, 335 (1983).

41. A.I. Onuchukwu, S.P. Trasatti and S. Trasatti, Corros. Sci., 36, 1815 (1994); https://doi.org/10.1016/0010-938X(94)90020-5.

42. S.A. Umoren, Y. Li and F.H. Wang, Corros. Sci., 52, 2422 (2010); https://doi.org/10.1016/j.corsci.2010.03.021.

43. D.Q. Zhang, L.X. Gao and G.D. Zhou, J. Appl. Electrochem., 33, 361 (2003); https://doi.org/10.1023/A:1024403314993.

44. A.Y. Musa, A.B. Mohamad, A.A.H. Kadhum, M.S. Takriff and L.T. Tien, Corros. Sci., 53, 3672 (2011); https://doi.org/10.1016/j.corsci.2011.07.010.

45. D. Jayaperumal, Mater. Chem. Phys., 119, 478 (2010); https://doi.org/10.1016/j.matchemphys.2009.09.028.

46. E.S. Ferreira, C. Giacomelli, F.C. Giacomelli and A. Spinelli, Mater. Chem. Phys., 83, 129 (2004); https://doi.org/10.1016/j.matchemphys.2003.09.020.

47. N. Goudarzi, M. Peikari, M.R. Zahiri and H.R. Mousavi, Arch. Metall. Mater, 57, 845 (2012); https://doi.org/10.2478/v10172-012-0044-1.

48. G.T. Xavier, B. Thirumalairaj and M. Jaganathan, Int. J. Corros., Article ID 410120 (2015); https://doi.org/10.1155/2015/410120.

49. S.T. Arab and A.M. Al-Turkustani, Port. Electrochim. Acta, 24, 53 (2006); https://doi.org/10.4152/pea.200601053.

50. I. Ahamad, R. Prasad and M.A. Quraishi, Corros. Sci., 52, 1472 (2010); https://doi.org/10.1016/j.corsci.2010.01.015. 